Beyond Borders 


\section{Asian History}

The aim of the series is to offer a forum for writers of monographs and occasionally anthologies on Asian history. The Asian History series focuses on cultural and historical studies of politics and intellectual ideas and crosscuts the disciplines of history, political science, sociology and cultural studies.

\section{Series Editor}

Hans Hägerdal, Linnaeus University, Sweden

Editorial Board Members

Roger Greatrex, Lund University

David Henley, Leiden University

Angela Schottenhammer, University of Salzburg

Deborah Sutton, Lancaster University 


\section{Beyond Borders}

Indians, Australians and the Indonesian Revolution, 1939 to 1950

Heather Goodall

Amsterdam University Press 
Cover illustration: Nationalist graffiti in a Surabaya street

(c) Imperial War Museum

Cover design: Coördesign, Leiden

Lay-out: Crius Group, Hulshout

$\begin{array}{ll}\text { ISBN } & 9789462981454 \\ \text { e-ISBN } & 9789048531103 \text { (pdf) } \\ \text { DOI } & 10.5117 / 9789462981454 \\ \text { NUR } & 692 \mid 697\end{array}$

(c) Heather Goodall / Amsterdam University Press B.V., Amsterdam 2019

All rights reserved. Without limiting the rights under copyright reserved above, no part of this book may be reproduced, stored in or introduced into a retrieval system, or transmitted, in any form or by any means (electronic, mechanical, photocopying, recording or otherwise) without the written permission of both the copyright owner and the author of the book.

Every effort has been made to obtain permission to use all copyrighted illustrations reproduced in this book. Nonetheless, whosoever believes to have rights to this material is advised to contact the publisher. 
For Paulie, Emma and Judith 
